\title{
Evaluating the Response of Mediterranean-Atlantic Saltmarshes to Sea-Level Rise
}

\author{
Miriam Fernandez-Nunez ${ }^{1, *(\mathbb{C}}$, Helene Burningham ${ }^{2}{ }^{\circledR}$, Pilar Díaz-Cuevas $^{3}$ and \\ José Ojeda-Zújar ${ }^{3}$ \\ 1 Geography, Geology and the Environment Department, Kingston University, Penrhyn road, \\ Kingston upon Thames KT12EE, UK \\ 2 Geography Department, University College London, Pearson Building, Gower Street, London WC1E 6BT, \\ UK; h.burningham@ucl.ac.uk \\ 3 Departamento de Geographia Fisica y AGR, Universidad de Sevilla, C/Maria de Padilla sn, 41004 Sevilla, \\ Spain; pilard@us.es (P.D.-C.); zujar@us.es (J.O.-Z.) \\ * Correspondence: m.fernandeznunez@kingston.ac.uk; Tel.: +44-(0)-2084174307
}

Received: 14 February 2019; Accepted: 5 March 2019; Published: 9 March 2019

\begin{abstract}
Saltmarshes provide high-value ecological services and play an important role in coastal ecosystems and populations. As the rate of sea level rise accelerates in response to climate change, saltmarshes and tidal environments and the ecosystem services that they provide could be lost in those areas that lack sediment supply for vertical accretion or space for landward migration. Predictive models could play an important role in foreseeing those impacts, and to guide the implementation of suitable management plans that increase the adaptive capacity of these valuable ecosystems. The SLAMM (sea-level affecting marshes model) has been extensively used to evaluate coastal wetland habitat response to sea-level rise. However, uncertainties in predicted response will also reflect the accuracy and quality of primary inputs such as elevation and habitat coverage. Here, we assessed the potential of SLAMM for investigating the response of Atlantic-Mediterranean saltmarshes to future sea-level rise and its application in managerial schemes. Our findings show that SLAMM is sensitive to elevation and habitat maps resolution and that historical sea-level trend and saltmarsh accretion rates are the predominant input parameters that influence uncertainty in predictions of change in saltmarsh habitats. The understanding of the past evolution of the system, as well as the contemporary situation, is crucial to providing accurate uncertainty distributions and thus to set a robust baseline for future predictions.
\end{abstract}

Keywords: sea-level rise; saltmarshes; coastal wetland management; SLAMM

\section{Introduction}

Saltmarsh ecosystems are considered to be particularly sensitive to changes in environmental forcing, especially to sea-level rise [1-3]. In order to understand the local response of these systems, it is essential to appreciate both global and local sea-level change and how these affect physical processes (e.g., inundation, sedimentation and salinity regime) and therefore ecosystem dynamics.

At the end of the 21st century, the rate of global sea-level rise (GSLR) is anticipated to be several times higher than that measured over the 20th century [4,5]. However, complex mechanisms over different time scales play crucial roles in sea-level change, which complicates the understanding of its impact [6,7]. Significant dissimilarities in future projections exist, varying from 0.28-0.98 $\mathrm{m}$ [7] over the period 1986-2005 and 2100 based on physical models (such as atmosphere-ocean general circulation models (AOGCM) that participated in Coupled Model Intercomparison Project 5 (CMIP5)) to $0.5-1.4 \mathrm{~m}$ [8] and 0.57-1.1 $\mathrm{m}$ [9] by 2100 (with respect to the 1990 and 1980-2000 level respectively) 
based on semi-empirical models. More recent studies that emphasize ice-sheet contributions to sea-level rise have estimated that the rise in global mean sea-level could exceed $2 \mathrm{~m}$ by 2100 [10,11]. The uncertainty in future sea-level predictions is significant, thus obscuring the magnitude of this phenomenon and the severity of possible impacts in coastal areas.

Although there are still uncertainties about future GSLR projections, two things are clear and certain: (i) that global sea level is rising and (ii) that it varies regionally. With respect to saltmarshes, Relative Sea-Level Rise (RSLR), which is affected by GSLR and vertical land movements [12], is a crucial variable for foreseeing potential impacts in specific coastal systems. The saltmarsh net elevation, and the balance between accretion and RSLR, will determine whether or not a saltmarsh will respond positively (vertical accretion > sea-level rise) or negatively (vertical accretion < sea-level rise; increasing the potential for permanent inundation) due to sea-level rise. Future net elevation is difficult to predict accurately due to complications in saltmarsh processes and responses [13], and uncertainties in future projections of GSLR and RSLR. Key linkages are non-linear, therefore historical data are only of limited value and process models are required for future predictions [14] and to assist long term management strategies.

Although saltmarshes provide high-value ecological services (such as coastal protection, food provision and carbon sequestration) [15] and play an important role in coastal ecosystems and populations, they still remain vulnerable to continued pressures from climate change and anthropogenic activities [16]. Saltmarshes face the threat of permanent inundation from accelerated sea-level rise combined with decreasing opportunities for upslope migration due to extensive human development of coastal areas [1,17]. In this context, those responsible for conservation and management decisions need appropriate tools with which to gauge the potential impacts of sea-level rise on saltmarshes and other intertidal ecosystems. However, within this is also the need for sensitivity and uncertainty analysis in order to evaluate the role of data quality and parameter uncertainties on predicted response. With this in mind, the aim of this paper is to assess the potential of the sea level affecting marshes model (SLAMM) [18] for investigating the response of Atlantic-Mediterranean saltmarshes to future sea-level rise. We also examine its use in managerial schemes, through the application of sensitivity and uncertainty analysis in the Odiel saltmarshes (Spain, Gulf of Cadiz).

SLAMM has been widely used in the USA to investigate the potential impacts of sea-level rise on saltmarshes [19-24]. It has not however been applied to Mediterranean-Atlantic saltmarshes (as classified by Reference [25] based on the distribution of saltmarsh flora), as found extensively in South West Europe and North Morocco (Gulf of Cadiz). The vegetation found in southwest Iberian saltmarshes tends to be different from that found in the Mediterranean basin or in Euro-Siberian saltmarshes and shows similarities to those found in North-Atlantic Africa. Saltmarsh habitats in the USA present dissimilarities to those located in SW Europe due to a range of differences in, for example, extent, vegetation type and structure. For example, saltmarshes in the Gulf of Cadiz comprise complex creek networks compared with the broad coastal tidal plains of the Atlantic US coast [26]. Despite its predominant use in the USA, it is still unclear whether SLAMM can be effectively used as a managerial tool in other parts of the world.

\section{Materials and Methods}

\subsection{Research Design}

The workflow of the approach carried out for this study is shown in Figure 1. This study first undertakes a sensitivity analysis to explore the relative importance of data quality and resolution in the elevation data and saltmarsh habitat classification layers. Monitoring and measurement of saltmarsh habitats are time-consuming and costly, and the acquisition of the SLAMM input layers can require significant resourcing. Some understanding of where surveying efforts should be focused is therefore necessary, particularly for authorities with financial constraints. Following this, an uncertainty analysis was performed on model inputs and different sea-rise scenarios for 2100 was undertaken to identify the 
important input parameters that control model output uncertainty and the chance of occurrence (taking in account the sea-level rise projection uncertainties for 2100). To that aim, the best quality spatial data (selected from the sensitivity analysis) and uncertainty distributions (model input parameters were randomly taken from these distributions explained in Section 2.5; the data to generate the distributions were taken from published data in the literature) are used to run SLAMM over the entire Odiel saltmarshes, where the potential saltmarsh response due to sea-level rise was assessed. Finally, erosion rates are investigated within the study area to assess the importance of this parameter within the system and their impact on future projections in Mediterranean-Atlantic saltmarshes.

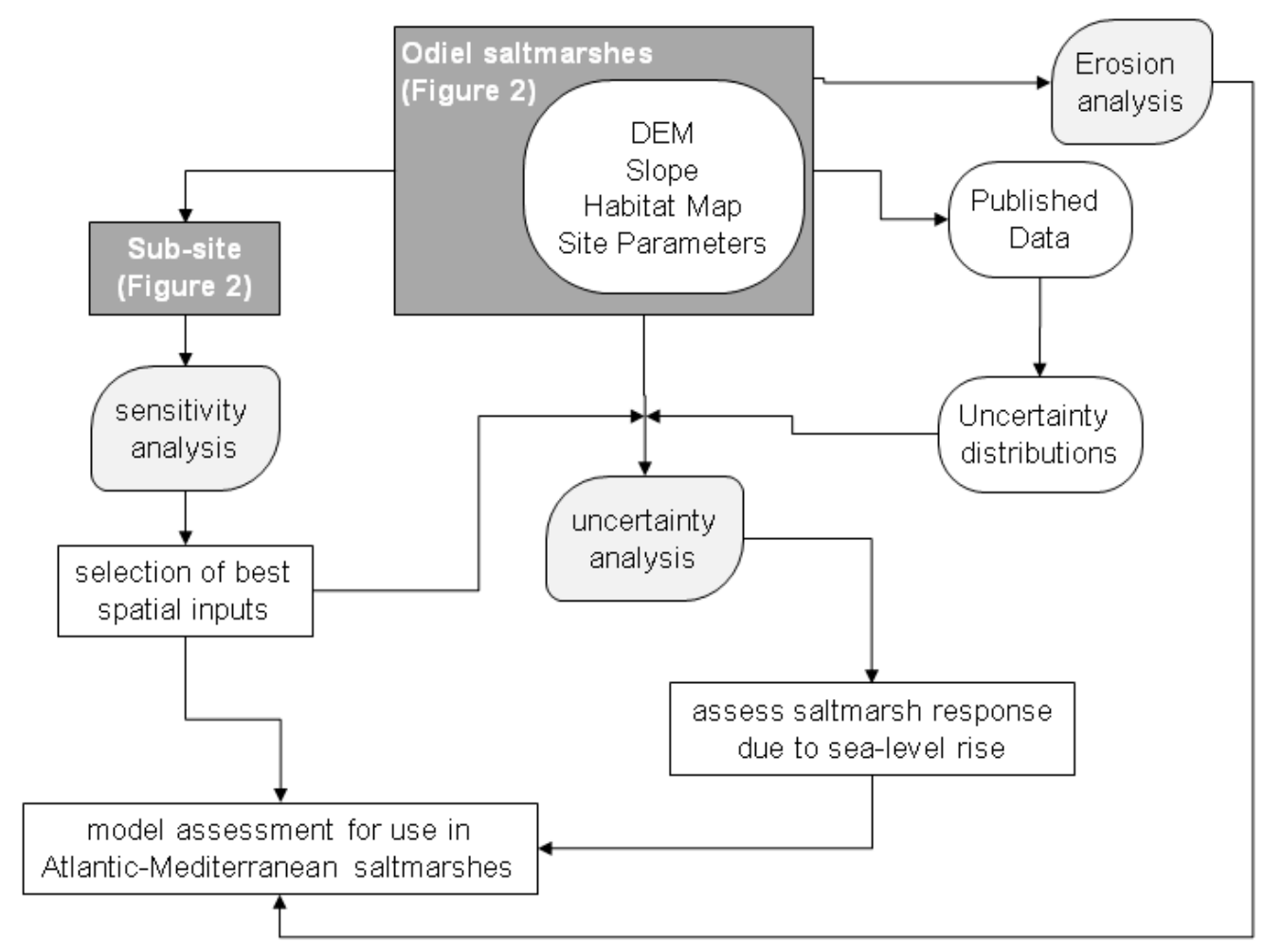

Figure 1. Workflow of the approach followed for this study.

\subsection{Study Area}

The Odiel saltmarshes of the Odiel-Tinto estuary (Figure 2) (Gulf of Cadiz, SW-Spain) comprise roughly 3000 ha of saltmarshes. The Tinto-Odiel estuary is situated in the central part of the Huelva coast adjacent to the North Atlantic. Coastal ecosystems here are representative of those found along the Gulf of Cadiz between Faro (Portugal) and Guadalquivir River (Spain) and North Africa, comprising sand spits, large dune systems, barrier islands and tidal inlets, landward of which are extensive saltmarshes, lagoons and estuaries that extend far into deeply carved river valleys [27,28]. The sensitivity analysis to assess spatial model inputs was undertaken on a smaller representative area of interest (sub-site shown in Figure 2) around Saltes Island, where habitats such as beaches, tidal flats, low marsh, high marsh, transitional marsh and up-land are found. Table 1 shows the habitats present and labels used in the SLAMM model habitat map. 


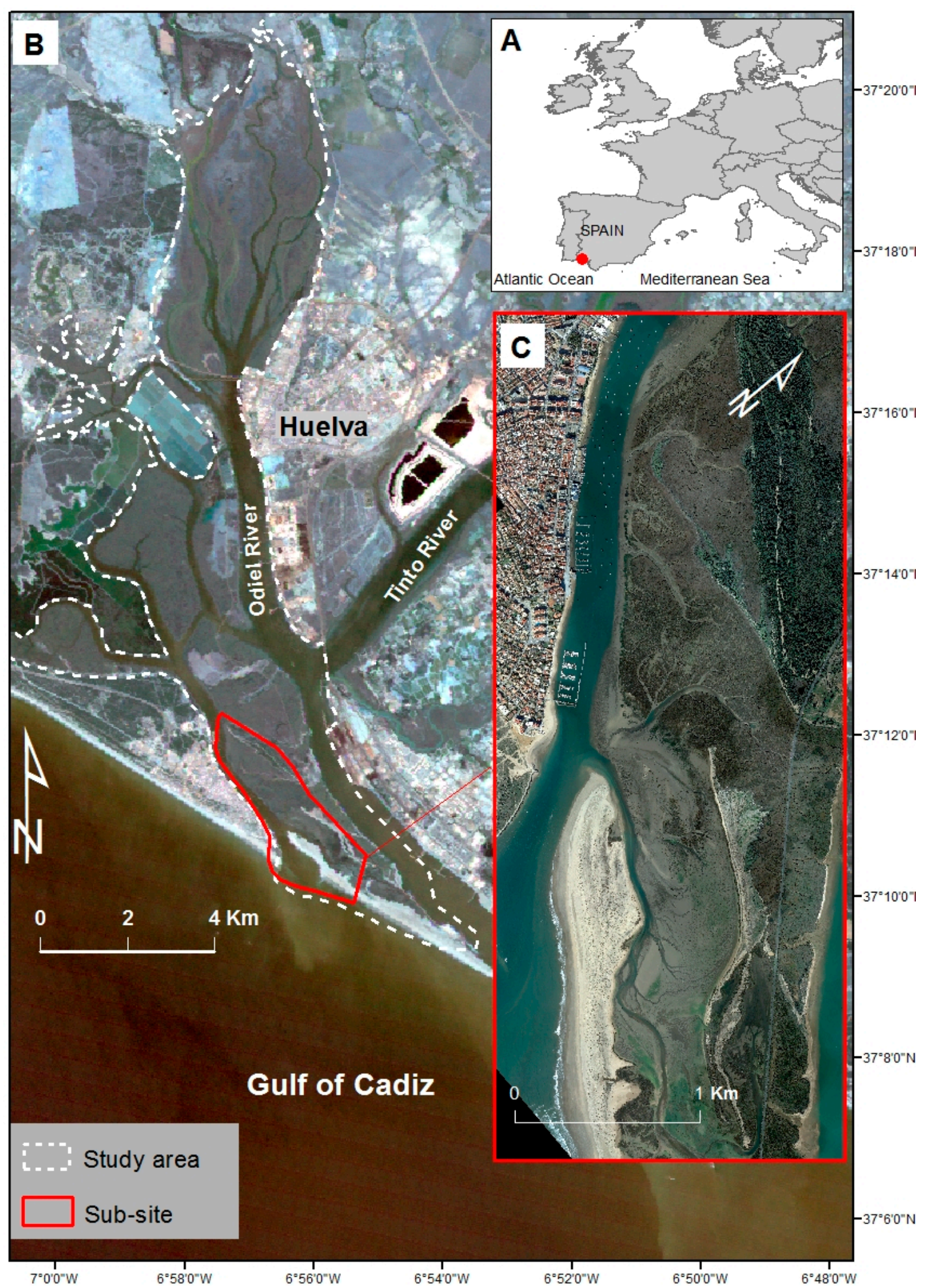

Figure 2. Location of the Odiel saltmarshes and the Tinto-Odiel Estuary (A,B), and location of the sub-site area of interest $(\mathbf{C})$ for testing model sensitivity to spatial inputs. 
Table 1. Description of the Odiel saltmarshes habitats with their equivalent SLAMM categories.

\begin{tabular}{cc}
\hline SLAMM Category & Description \\
\hline Dry-land & Upland (above Highest Astronomical Tide) \\
Transitional Salt Marsh & Estuarine intertidal scrub-shrub \\
Irreg.Flooded Marsh & High saltmarsh \\
Reg.Flooded Marsh & Low saltmarsh \\
Ocean Flat & Marine intertidal unconsolidated shore mud or organic \\
Tidal Flat & Estuarine intertidal unconsolidated shore mud or flat \\
Estuarine Beach & Estuarine intertidal unconsolidated shore sand or beach-bar \\
Ocean beach & Marine intertidal unconsolidated shore sand \\
Backshore & Dry part of an active beach (located above Mean Higher High Water) \\
Estuarine water & Estuarine water \\
\hline
\end{tabular}

\subsection{SLAMM Model}

SLAMM version 6.2 (Warren Pinnacle Consulting, Inc., Warren VT, Washington, WA, USA) [29] was used for this study. This model simulates six key processes/factors involved in wetland conversions and shoreline modifications during sea-level rise: inundation, accretion, erosion, overwash, saturation, and salinity. In order to simulate these processes, SLAMM uses spatial data including digital elevation model (DEM), slope and wetland category maps, and site-specific parameters such as tidal range or accretion rates. To represent conversion among wetland classes, SLAMM uses a flexible and complex decision tree incorporating geometric and qualitative relationships [29].

Wetland conversion under sea-level change occurs when sea-level rise exceeds accretion rates and when the minimum elevation of a cell is below the minimum elevation for a specific wetland category. The wetland lost fraction (which it is transferred to another category) is calculated as a function of the cell slope, the minimum elevation for that category, and the lower elevation boundary for that category [29]. Erosion will occur for those categories adjacent to water when the maximum fetch for a certain cell is greater than $9 \mathrm{~km}$.

\subsection{Sensitivity Analysis of Spatial Model Inputs}

A sensitivity analysis was organized to evaluate the role of model input data quality and resolution, considering both the elevation and habitat inputs. As sensitivity relative to habitat cover has not been explored previously, the effort here focused on investigating how detail and resolution in this input layer affect model results (especially for those saltmarshes found in SW Europe, which are characterized by complex creeks system). However, it should be noted that the presence and complexity of creek systems vary considerably between marsh systems, so changing the resolution in spatial inputs has the potential to represent a different type of saltmarsh system. These test runs were undertaken across a smaller, but a representative region within the Odiel saltmarshes around Saltes Island (Figure 2). The model inputs tested in this analysis (Table 2) were the marsh habitat map (MHM) (Figure 3), the digital elevation model (DEM), and the elevation range for each habitat category. The SLAMM categories used in Figure 3 are described in Table 1, where 'dry-land' integrates 'developed land' and 'undeveloped land'. 'developed land' refers to upland environments (i.e., built environments, farmlands) that have been defended against sea-level rise and 'undeveloped land' refers to upland environments that have not been defended. The variation in surface area for each marsh habitat maps is specified in Figure 4.

Site parameters were kept constant and are summarized in Table 3, and the five sets of tests are summarized in Table 4. Test 1 explored the impact of cell resolution, and following this, the optimum (defined as the cell size that optimizes running time without compromising spatial information) cell size was then used for the remaining tests. Hence, Test 1 with the optimum cell size is used as the base case, and thus overlaps with the base case for the other tests. Test 2 explores the role of the marsh habitat map, represented by four different resolutions (MHM_1, MHM_2, MHM_3 and MHM_4); Test 3 explores the role of habitat elevation range inputs. Test 4 investigates the benefit 
of using high-resolution habitat maps when only poor resolution DEMs are available, and here, the elevation pre-processor tool is also tested. This tool is used when high-quality elevation data are not available, and estimates elevation ranges as a function of tide ranges and known relationships between wetland types and tide ranges (see Reference [29]). Finally, Test 5 explores the differences between the Lidar-derived DEM and a habitat-corrected Lidar-derived DEM [30].
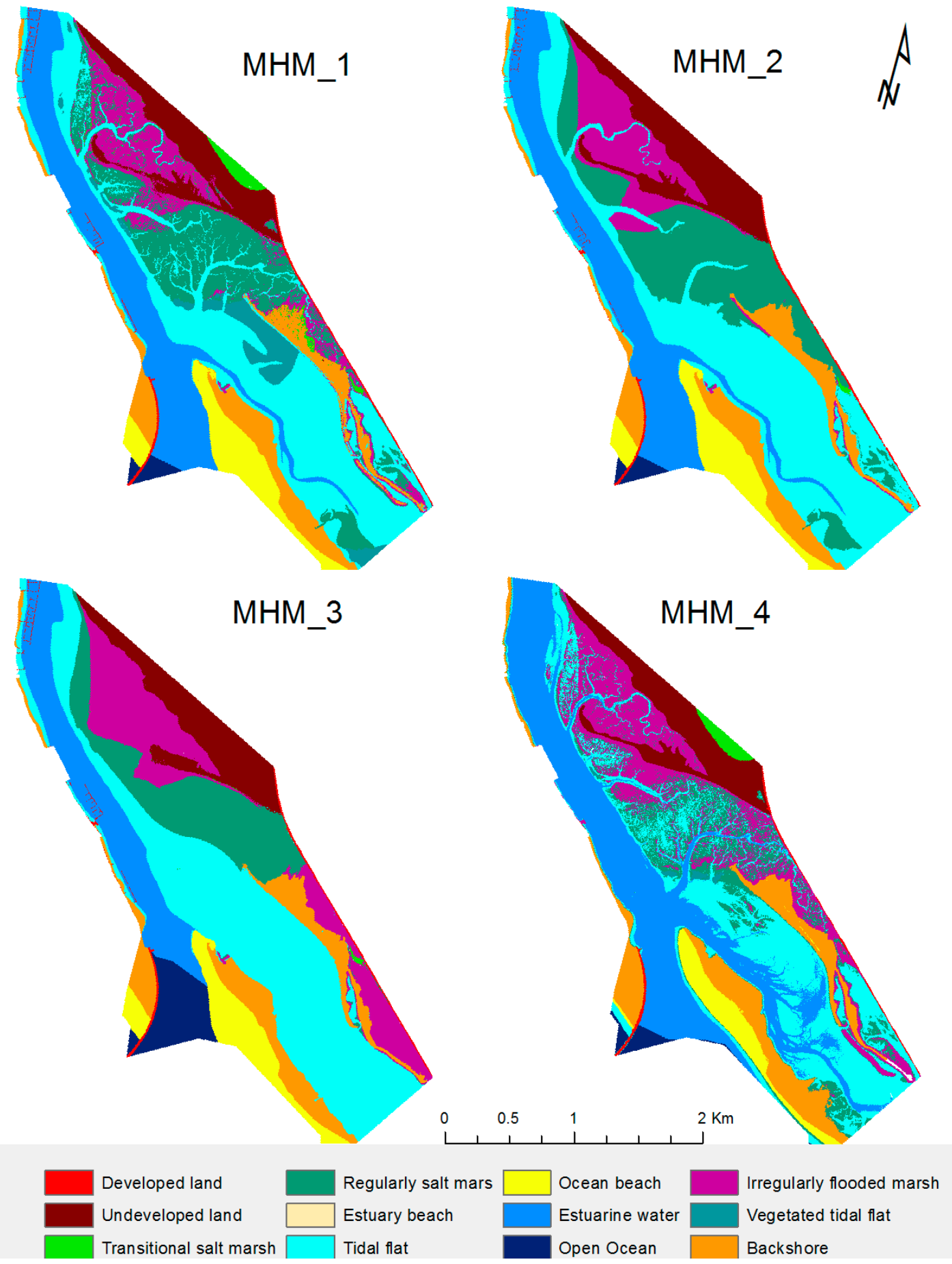

Figure 3. Marsh habitat maps (MHM) from Table 2 used as different spatial inputs for testing SLAMM. 


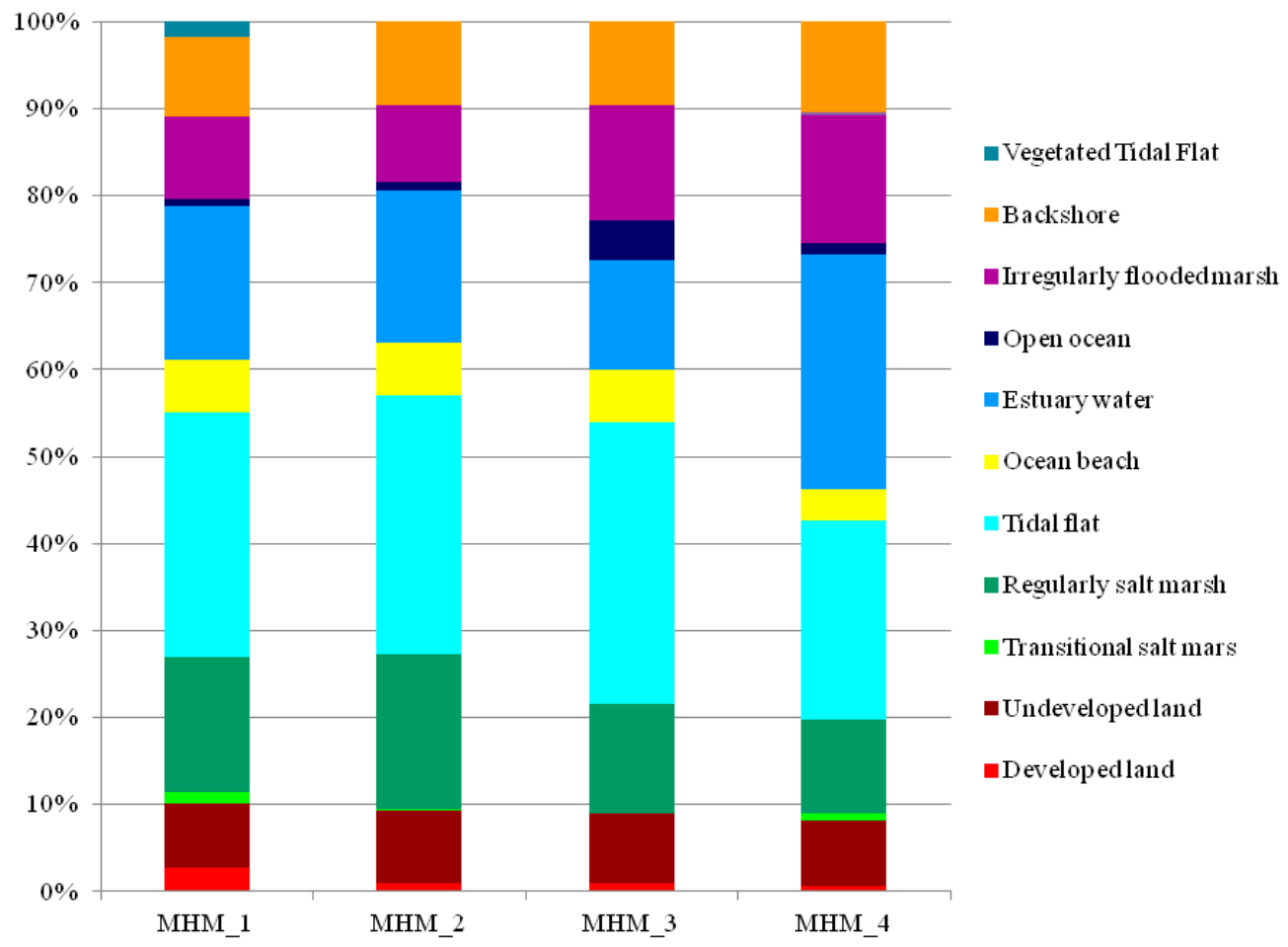

Figure 4. Variation in surface area (\%) for each marsh habitat maps (MHM) from Figure 3.

Table 2. Summary of data used as inputs in SLAMM.

\begin{tabular}{|c|c|c|}
\hline Name & Description & Source \\
\hline DEM_1 & Unmodified LiDAR-derived DEM (1 m spatial resolution). & [31] \\
\hline DEM_2 & $\begin{array}{l}\text { Modified LiDAR-derived DEM (1 m spatial resolution). DEM_1 } \\
\text { was corrected using a habitat-specific correction factor }\end{array}$ & [30] \\
\hline DEM_3 & DEM of the Andalusian Coast (10 m spatial resolution) & $\begin{array}{l}\text { Andalusian Environmental } \\
\text { Ministry }\end{array}$ \\
\hline MHM_1 & $\begin{array}{l}\text { Marsh Habitat Map derived from supervised classification using } \\
2013 \text { aerial photography and DEM_2 (1 m spatial resolution) }\end{array}$ & [31] \\
\hline MHM_2 & $\begin{array}{l}\text { Manual simplification of MHM1 ( } 5 \mathrm{~m} \text { spatial resolution) to } \\
\text { remove small creeks (retains main creeks) }\end{array}$ & $\begin{array}{l}\text { Derived from MHM1 } \\
\text { (e.g., fewer small creeks) }\end{array}$ \\
\hline MHM_3 & $\begin{array}{l}\text { Manual simplification of MHM2 (5 m spatial resolution) to } \\
\text { remove all creeks (only the main tidal channels remain) }\end{array}$ & $\begin{array}{l}\text { Derived from MHM2 } \\
\text { (e.g., only the main channel) }\end{array}$ \\
\hline MHM_4 & $\begin{array}{c}\text { Reclassification of DEM2 based on habitat elevation range. For } \\
\text { Upland categories and backshore (where the height range } \\
\text { overlaps, manual editing was carried out) }\end{array}$ & Derived from DEM2 \\
\hline EIN & $\begin{array}{l}\text { Elevation inputs (EINs) per habitat category (zonation) EIN_a } \\
\qquad( \pm 0.2 \mathrm{~m}) ; \text { EIN } \_b( \pm 0.4 \mathrm{~m})\end{array}$ & [32] \\
\hline
\end{tabular}

Table 3. Site-specific input parameters required for SLAMM.

\begin{tabular}{lc}
\hline \multicolumn{2}{c}{ Input Parameters } \\
\hline Description & Punta Umbría Ria \\
\hline Habitat Map Photo Date (YYYY) & 2013 \\
Digital Elevation Model Date (YYYY) & 2013 \\
Direction Offshore (n, s, e, w) & South \\
Historic Trend (mm/year) & 3.3 \\
Mean Tide Level - Vertical datum (m) & 0.39 \\
Great Diurnal Tide Range (m) & 3.11 \\
Salt Elev. (m above MTL) & 2.09 \\
Marsh Erosion (horz. m/year) & 0.0105 \\
T.Flat Erosion (horz. m/year) & 0.003 \\
Reg. Flood Marsh Accr (mm/year) & 6.57 \\
Irreg. Flood Marsh Accr (mm/year) & 2.5 \\
\hline
\end{tabular}


Table 4. Summary of the test specifications used for running sensitivity analysis in SLAMM.

\begin{tabular}{|c|c|c|c|c|c|}
\hline Description & Test 1 & Test 2 & Test 3 & Test 4 & Test 5 \\
\hline Cell size $(\mathrm{m})$ & $3,5,10$ & 5 & 5 & 5 & 5 \\
\hline Digital Elevation & DEM_2 & DEM_2 & DEM_2 & DEM_3 & DEM_1 \\
\hline $\begin{array}{l}\text { Marsh Habitat } \\
\text { Map }\end{array}$ & MHM_1 & $\begin{array}{l}\text { MHM_1 } \\
\text { MHM_2 } \\
\text { MHM_3 } \\
\text { MHM_4 }\end{array}$ & MHM_1 & $\begin{array}{l}\text { MHM_1 } \\
\text { MHM_3 }\end{array}$ & MHM_1 \\
\hline Elev. Prep* & False & False & False & False/True & False \\
\hline $\begin{array}{l}\text { Elevation ranges } \\
\text { (zonation) }\end{array}$ & EIN & EIN & $\begin{array}{c}\text { EIN } \\
\text { EIN_a }( \pm 0.2 \mathrm{~m}) \\
\text { EIN_b }( \pm 0.4 \mathrm{~m})\end{array}$ & EIN & EIN \\
\hline
\end{tabular}

* Elevation pre-processor available in SLAMM.

\subsection{Uncertainty Analysis}

SLAMM (v-6.2, Warren Pinnacle Consulting, Inc., Warren VT, Washington, WA, USA) has the ability to perform uncertainty analysis using a Monte-Carlo approach to provide confidence statistics for model results as a function of input uncertainties. The Monte-Carlo framework implemented the following steps:

1. Define the input uncertainty distributions

2. Decide how many simulations lead to results which are robust (i.e., not seed sensitive) and accurate.

3. Automatically generate random input values consistent with the uncertainty distributions.

4. Run SLAMM multiple times with these pseudorandom inputs to evaluate how SLAMM outputs are affected (full calculation).

5. Analyze the distribution of the model output outcomes to see if there are any common patterns helping the user to understand the dynamics/interaction of the previously defined uncertainty distributions of the model inputs.

Uncertainty distributions (step 1) were constructed for each of the model inputs, where it was assumed that the inputs follow a triangular distribution. Triangular distributions give more importance to the extreme values that normal distributions, which has been effectively demonstrated in similar analyses elsewhere (e.g., Reference [33]). It is assumed that the uncertainty distributions of the accretion rates of both regularly and irregularly flooded marshes follow a joint distribution, but the other parameters were assumed to be independent of each other. The $\mathrm{SLR}_{2100}$ distribution values were defined using different published projections for global sea-level rise by 2100 range between 0.6 and $2.5 \mathrm{~m}$ (based on IPCC-scenarios and predictions from References $[4,8]$ ); the local historical sea-level rise trend $\left(\mathrm{H}_{\text {trend }}\right)$ used the observed local (Gulf of Cadiz) minimum, maximum and most likely (average) [34] (source: PSMSL); and the regularly flooded marsh accretion (reg-accre) and regularly flooded marsh accretion (irreg-accre) used the published Odiel saltmarshes accretion rates [35]: Minimum ( -3 standard deviations of the manifested values), maximum ( +3 standard deviations of the manifested values) and most likely (average of the manifested values).

The next steps were to determine the number of simulations (step 2) and to generate random inputs (following the uncertainty distributions) for the model (step 3). The number of simulations (N) for performing uncertainty analysis was determined using Equation (1) (proposed in Sobol's method [36]), and used by Reference [33] to perform uncertainty analysis):

$$
\mathrm{N}=(\mathrm{k}+2) \times \mathrm{M}
$$


where $\mathrm{k}$ is the number of input factors and $\mathrm{M}$ is the sample size (usually between 500 and 1000). In this analysis, there were four input factors $\left(\mathrm{SLR}_{2100}\right.$, Hist $t_{\text {trend }}$, reg-accre and irreg-accre) and the value of $\mathrm{M}$ was 1000 , leading to a total of 10,000 simulations.

Step 4 following a full calculation approach would require 10,000 simulations using the randomly generated model inputs to calculate the final output of saltmarsh cover classifications by the year 2100 . Computing time required for this is $\sim 1666 \mathrm{~h}$ so an alternative sub-sampling approach was used [31]. Here, a full calculation was performed on a set of input values ( 15 values for each parameter, which means $\sim 60$ model runs) covering the range of the uncertainty distribution defined for each input factors. The outputs obtained using the mentioned set of inputs values were tested and showed a linear distribution. Thus, the rest of the outputs (9940) were estimated using linear interpolation. The computing time here was reduced to roughly $6 \mathrm{~h}$, making this approach feasible for this work using a single computer.

\subsection{Erosion Rates}

Shoreline erosion and saltmarsh accretion rates were examined throughout the Odiel estuary. As SLAMM do not take in account erosion values when the fetch is smaller than $9 \mathrm{~km}$, it was important to investigate the importance and contribution of these values in the system dynamic (marsh loss or gain). It should be noted that erosion along marsh boundaries can be an important sediment source for the accreting marsh system (but may favor edge accretion rather than supply to the whole marsh), and SLAMM do not take in account this process. In this work, erosion rates were determined through the analysis of shoreline evolution from aerial photographs between 1956 and 2013.

Saltmarsh shorelines were digitized as polylines using ArcGIS v10.2 (Environmental Systems Research Institute, Redlands, CA, USA); for the years 1956, 1979, 1984, 2001 and 2013 using the vegetation boundary as the marsh boundary indicator. This indicator was selected due to its stability over time [37] and due to its unambiguous presence in the aerial imagery. Decadal rates of shoreline change were derived using the digital shoreline analysis system (DSAS v4.0 (US Geological Survey, Reston, VA, USA); [38]) at $100 \mathrm{~m}$ intervals (782 transects) along the saltmarsh shoreline. DSAS has been widely used to determine shoreline change in different coastal environments, (e.g., References [39,40]). The linear regression rate-of-change (LRR), determined by fitting a least squares regression line to all shoreline points for a particular transect [38] was used here as it expresses a rate of change that takes into account all time steps across the available data. The LRR statistic was adopted after assessing different statistic for estimating shoreline rate-of-change in DSAS. For example, endpoint rate (EPR) statistics (which only uses the initial and final years) masked some inter-decadal variability that was picked up in the LRR statistic. In the case of weighted linear regression (WLR), although WLR statistics addresses differences in uncertainties in different shoreline sources, it was not relevant for this study because there is no significant difference in the accuracy of the surveys (aerial photography).

\section{Results}

\subsection{Sensitivity Analysis Based on Spatial Inputs}

The results suggested that the role of elevation is the most important factor in controlling model outputs. The role of the marsh habitat map is also important; however, it does not have the same impact on all the defined categories. The spatial model results for the tests performed are compared in Figure 5 . These results are reported by test type and saltmarsh habitat categories. 

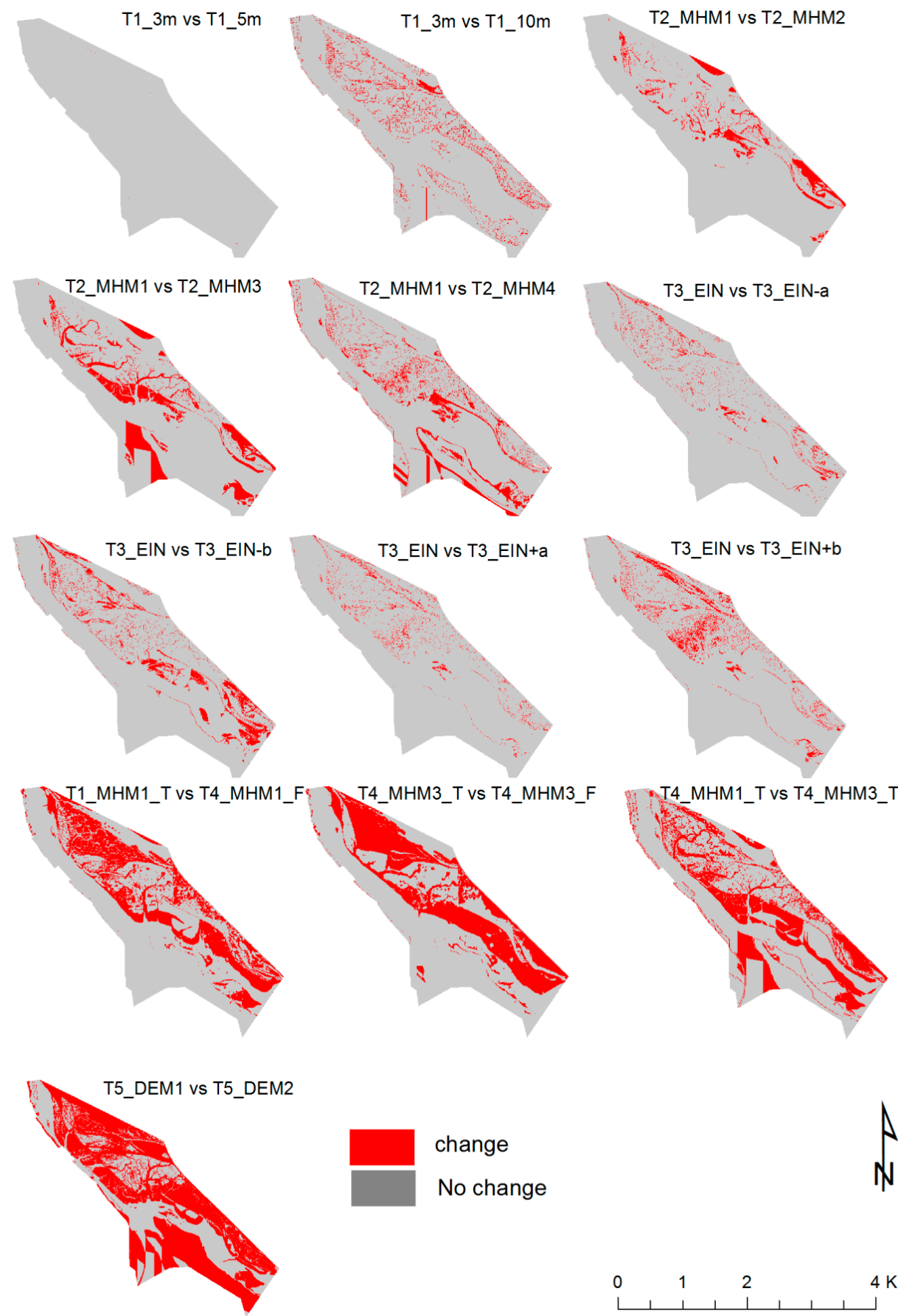

$N$

Figure 5. Comparison of the result obtained per test performed. $T_{i}$ indicates the test carried (e.g., test 1 , test 2 , etc.) followed by the specific input that was modified within each test, where MHM refers to map habitat map, DEM to the digital elevation model, EIN to elevation inputs and '3/5/10 m' to the cell size. The pre-processor tool was (by default) off in all the tests, and only in test 4 (T4) was on (stated by ' $\mathrm{T}$ ') and off (stated by ' $\mathrm{F}$ ') to compare the utility of high-resolution habitat maps when high-resolution DEM is not available (see Tables 2 and 4).

With regards to the test type, Test 1 showed that the cell size does not have a great impact in outputs when $3 \mathrm{~m}$ and $5 \mathrm{~m}$ cell sizes are used. The model outputs slightly varied when a $10 \mathrm{~m}$ cell size is used (Figure 5), especially for transitional saltmarshes and undeveloped dry land (Figure 5). Thus, there is a minimal gain in implementing SLAMM with a cell size less than $5 \mathrm{~m}$; SLAMM is flexible 
with regard cell sizes, cell widths usually range between $5 \mathrm{~m}$ and $30 \mathrm{~m}$ depending on site and input data availability [29].

The sensitivity of SLAMM to different habitat maps was evaluated in Test 2; habitat map resolution considerably influences model results (Figure 6), highlighting the importance of habitat mapping, especially in open water, estuarine water and saltmarsh categories such as irregularly flooded marsh and vegetated tidal flat. The impact on the two first categories is due to elevation input ranges for these categories, which are not defined in SLAMM. Thus, habitat maps strongly control these two categories. For example, in Figure 6 creeks are evident as only main channels are included in MHM3. Distances from creeks are used in the accretion sub-model integrated into SLAMM, affecting habitat conversion. In the case of MHM1 and MHM4, two habitat maps of the same resolution are compared. The results here showed some differences as well, but these are distributed across the saltmarsh, and along the margins. The results show that high-resolution habitat maps that represent the complexity of habitats present (e.g., creeks system) are essential (even when the pre-processor tool is not used), and this has not been clearly highlighted by other SLAMM users thus far.

Test 3 shows the importance of the habitat elevation range predefined within the model. Variations of just a few centimeters in the vertical influence the model output and show the importance of correctly defining the habitat elevation ranges, and also imply that these range inputs should be site specific. Test 4 shows model output differences when the pre-processor tool is on and off, using a low-resolution DEM and either the high or low-resolution habitat maps. Results significantly changed when the pre-processor tool was turned on in both cases. As expected, the model is sensitive to a change in the resolution of the habitat map when the pre-processor tool is on and a low-resolution DEM is used, showing important changes when both output results are compared.

Test 5 compares the model results when the LiDAR-derived DEM (DEM1) and modified (using a habitat-specific correction factor) DEM (DEM2) are used. Results showed that small differences in the saltmarsh elevation model $(<0.5 \mathrm{~m})$ affect model outputs, highlighting the importance of knowing the real elevation accuracy over the saltmarsh platform. The accuracy over high-density tall vegetation in saltmarshes can be significantly different than bare ground or areas covered by short vegetation when LiDAR-derived DEMs are used.

With regard to habitat category, the variation in surface area by habitat type is shown in Figure 5; only the main changes for saltmarsh habitats are reported. Results for regularly flooded marsh were sensitive to habitat map resolution. For example, when habitat maps MHM2 and MHM3 were used, outputs differ from the best estimate (MHM1) by roughly 10 ha ( $\sim \%$ and $-7 \%$ respectively). The results showed a similar surface area when MHM1 and MHM4 were used $(\sim 0.2 \%$ change respect the base case). Thus, this category can be based on elevation data if a high-resolution habitat map is not available. However, this category is very sensitive to DEM resolution and elevation ranges. When these variables were tested, the results varied from 20 to 70 ha (from $~ 14 \%$ to $44 \%$ ).

Irregularly flooded marsh did not change with cell size nor when MHM2 was used. However, the results varied slightly when habitat maps MHM3 ( 2 ha less than MHM) and MHM4 ( 2 ha more than MHM1) were used. This category was sensitive to DEM spatial resolution and elevation range. Outputs varied greatly (more than 50 ha) when the elevation pre-processor was used in Test 4.

Tidal flat outputs were very sensitive to habitat map variation, resulting in very different output surface area-approximately 20 ha for MHM1, 36 ha for MHM2, 55 ha for MHM3 and 12 ha for MHM4. The variation of surface area is due to the representation in MHM2 tidal creeks has been simplified and in MHM3 they have been deleted. In the case of MHM4, the channel system is also different from MHM1 as this map is based on elevation. This category was sensitive to DEM spatial resolution and elevation ranges. Again, outputs varied greatly (more than 50 ha) when the elevation pre-processor was used in Test 4 . 
Developed Dry Land

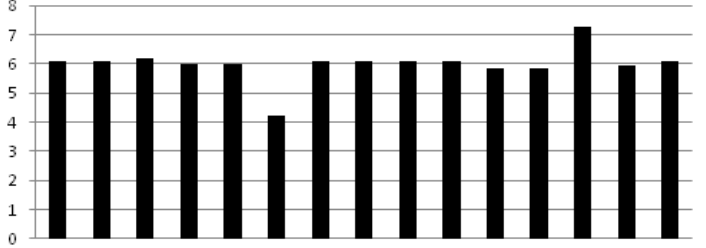

Trans. Salt Marsh

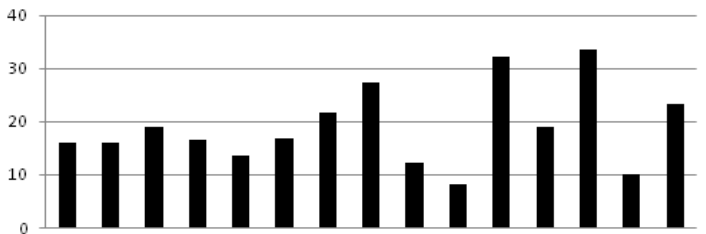

Irreg. Flooded Marsh

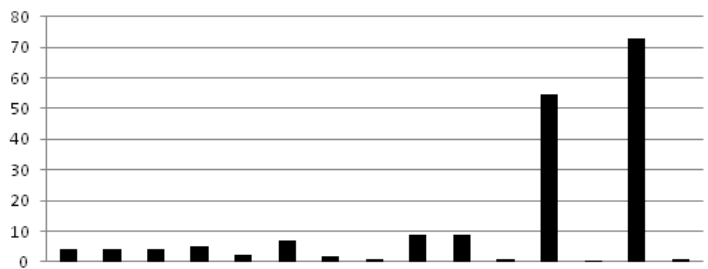

Vegetated Tidal Flat

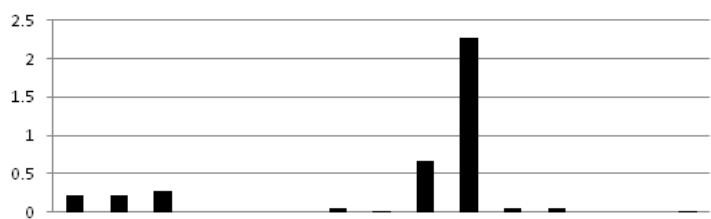

Estuarine Open Water

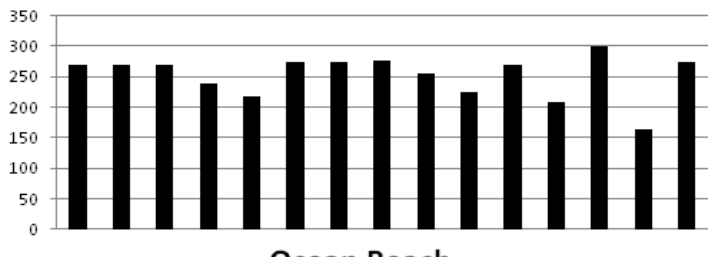

Ocean Beach

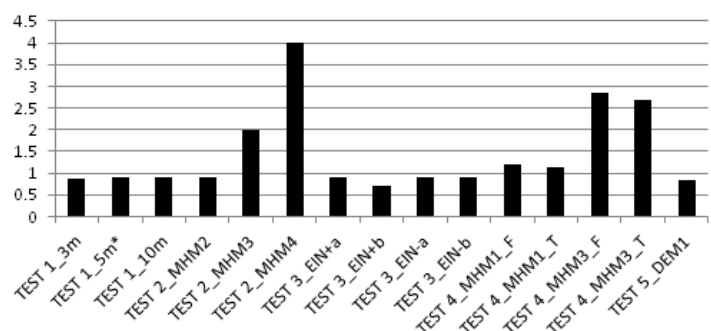

Undeveloped Dry Land

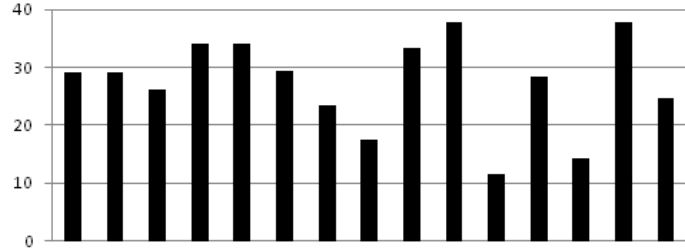

RegularlyFlooded Marsh

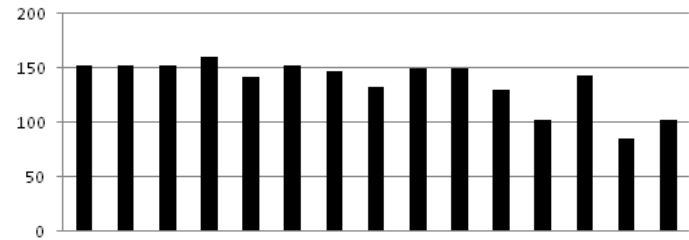

Tidal Flat

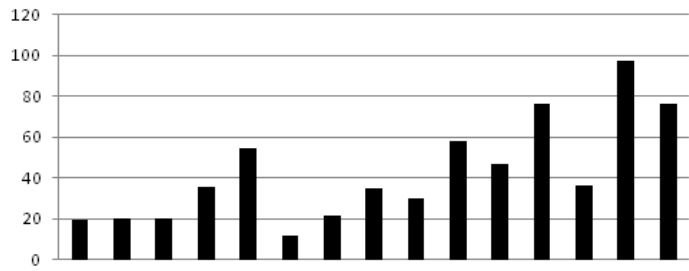

Estuarine Beach

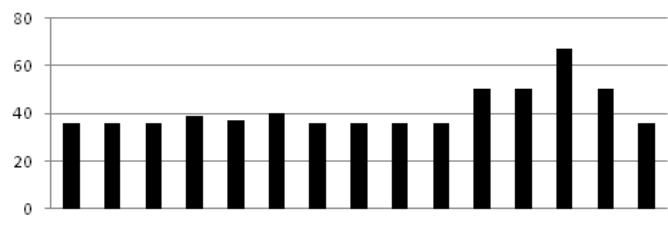

Open Ocean

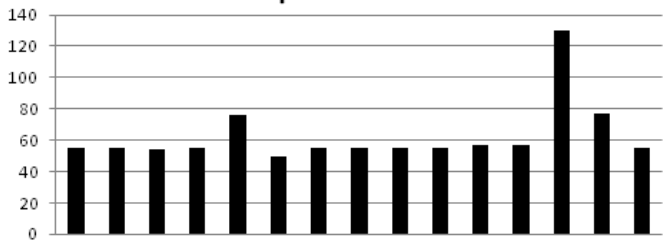

Backshore

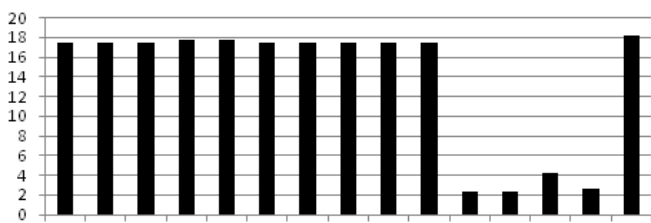

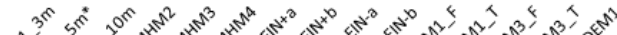

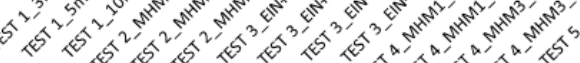

Figure 6. Surface areas (in hectares) of the outputs for $0.5 \mathrm{~m}$ sea level rise projected for 2100 and its variation per category when different inputs are used the optimum test across all categories is Test 1_5 $\mathrm{m}$ (which uses the highest resolution input data). * This test out is the same as Test 2_MHM1, Test 3_EIN and Test 5_DEM2. 


\subsection{Uncertainty Analysis}

The uncertainty analysis captured the range of variability of each output (in terms of habitat surface area). This work is primarily interested in how the 'total saltmarsh' fares in the simulations, thus, for simplicity, the saltmarsh categories have been added together. The 'total saltmarsh' is defined as the combination of regularly flooded marsh, irregularly flooded marsh, and transitional marsh categories. The uncertainty here is assessed in two ways. The first is based on the uncertainty of the future sea-level rise by 2100 (keeping the other input factors constant). The second assessment is based on the uncertainty of the Htrend, reg-accre and irreg-accre input factors for a $1 \mathrm{~m}$ sea-level rise by 2100 . For a given set of 10,000 outputs (obtained using a full calculation with linear interpolation), the total saltmarsh changes were ordered from the largest negative to the largest positive, and the frequency distribution was calculated as shown in Figures 7 and 8.

The effect of the $1 \mathrm{~m}$ scenario sea-level rise using the full range variability of input factors was evaluated by analyzing the variability of the outputs. Interestingly, total saltmarsh showed a bimodal distribution, with peaks representing both negative and positive change (Figure 7). Overall, 4401 simulations showed a decline of the total saltmarsh, which can be interpreted as a $44 \%$ chance of this happening; 214 simulations showed complete elimination of marsh ( $<1 \%$ chance of occurring). On the other hand, 5599 simulations express an increase in total saltmarsh ( $56 \%$ chance). This is encouraging as it captures the potential for saltmarsh creation under a rising sea-level given a suite of favorable factors (related to sedimentation rates).
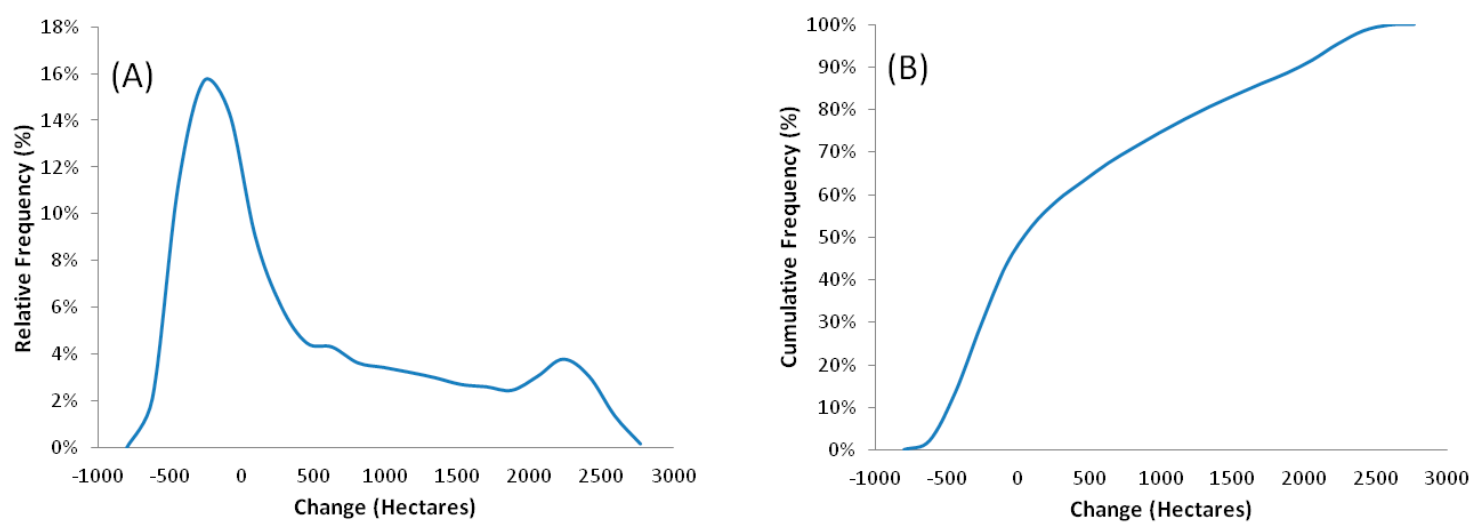

Figure 7. Uncertainty analysis for the total saltmarsh considering $1 \mathrm{~m}$ sea-level rise scenario and the full variability of the input factors (Htrend, reg-accre and irreg-accre), where (A) shows the relative frequency of the range of outputs variability (\%), and (B) the cumulative frequency (\%).

The effect of different sea-level rise scenarios (using the $\mathrm{SLR}_{2100}$ uncertainty distribution) on model uncertainty was also evaluated from the variability in total saltmarsh outputs. The total saltmarsh shows a unimodal distribution, where 7270 simulations exhibited a decline in total surface area relative to the base case (73\% probability). However, the highest relative frequency (Figure $8 \mathrm{~A}$ ) shows that there is a $22 \%$ chance of losing between $52 \%$ and $66 \%$ of the overall saltmarsh when uncertainty is only based on sea-level rise scenarios. There are 2730 simulations exhibiting an increase in saltmarsh area ( $27 \%$ probability). The probability of losing saltmarsh is higher when only sea-level rise scenarios are considered, highlighting the importance of accretion in the sustainability of these environments. 

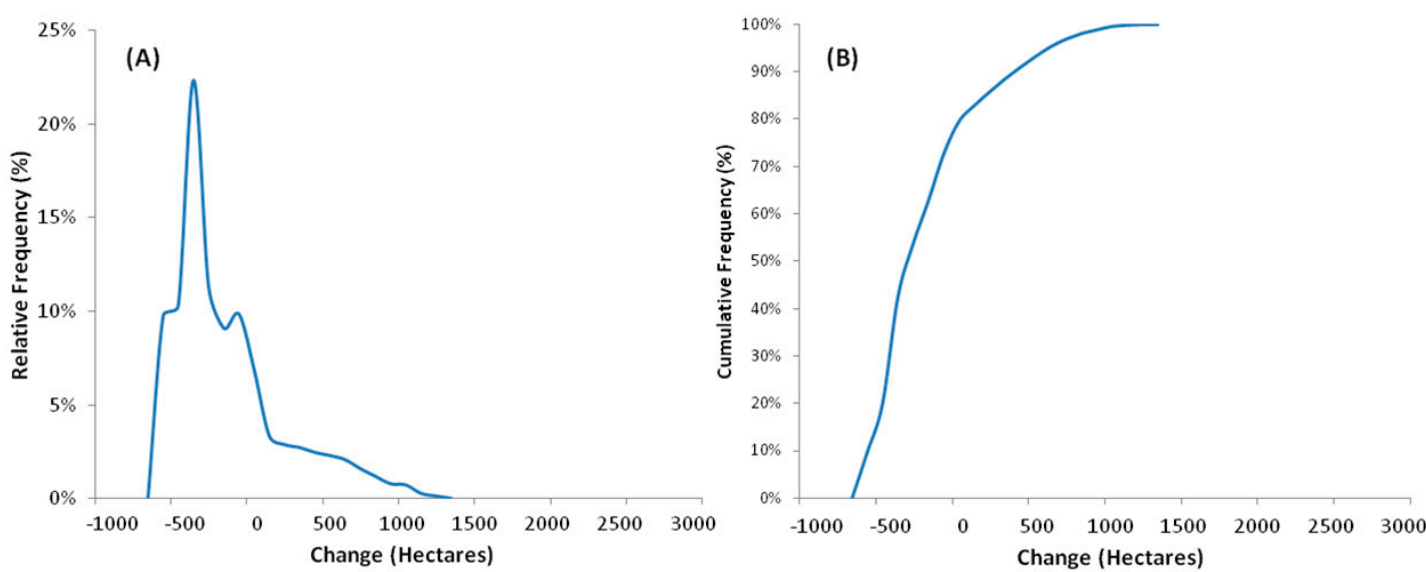

Figure 8. Uncertainty analysis for the total saltmarsh considering the full variability of the sea-rise scenarios defined in the uncertainty distributions, where (A) shows relative frequency of the range of outputs variability (\%), and (B) the cumulative frequency (\%).

Relative to the initial case (2013), keeping the site parameters constant, the worst estimate was a loss of $98 \%$ of vegetated saltmarshes by 2100 under a sea-level rise scenario of $2.3 \mathrm{~m}$; the best estimate was a loss of $91 \%$ under a sea-level scenario of $0.6 \mathrm{~m}$. However, when saltmarsh accretion increased over time, the total saltmarsh loss was reduced leading to the best estimate loss of $7 \%$ (under a $1 \mathrm{~m}$ sea-level rise, assuming $3.5 \mathrm{~mm}_{\text {year }}{ }^{-1}$ historical sea level trend, $18.5 \mathrm{~mm}_{\text {year }}{ }^{-1}$ accretion rates in regularly flooded marsh and $2.6 \mathrm{~mm}_{\text {year }}{ }^{-1}$ in irregularly flooded marsh). These findings demonstrate once again the importance of future accretion rates (notably sediment availability and supply) in the fate of the Odiel saltmarshes.

\subsection{Assessment of the Erosion Rates}

Erosion is also an important factor in saltmarsh loss, and it could exacerbate the impacts of sea-level rise. However, as it was mentioned previously SLAMM does not take into account erosion when the fetch is smaller than $9 \mathrm{~km}$. This is the case of the Odiel saltmarshes, and thus erosion was not considered in the results. In order to assess the importance of this parameter in our study site erosion rates within the saltmarsh were estimated. Overall, the results showed that erosion is a relevant parameter and it is essential to model saltmarsh future projections in a context of sea-level rise.

The most striking result in the analysis of saltmarsh shoreline change is the significant difference in behavior between the northern and southern marshes over recent decades (1956-2013). The Odiel saltmarshes in the mid/lower estuary have mostly retreated whereas those in the upper estuary have mostly advanced (Figure 9). Within the upper estuary, the greatest growth is experienced on the east shore of the Retamal creek, where the horizontal growth rate is $>2.5 \mathrm{~m}_{\text {year }}{ }^{-1}$. Saltmarsh shorelines associated with the islands within the mid/lower estuary show recession over the same time frame: Enmedio Island, for example, has eroded at a rate of $0.5-2.5 \mathrm{~m}_{\text {year }}{ }^{-1}$. 


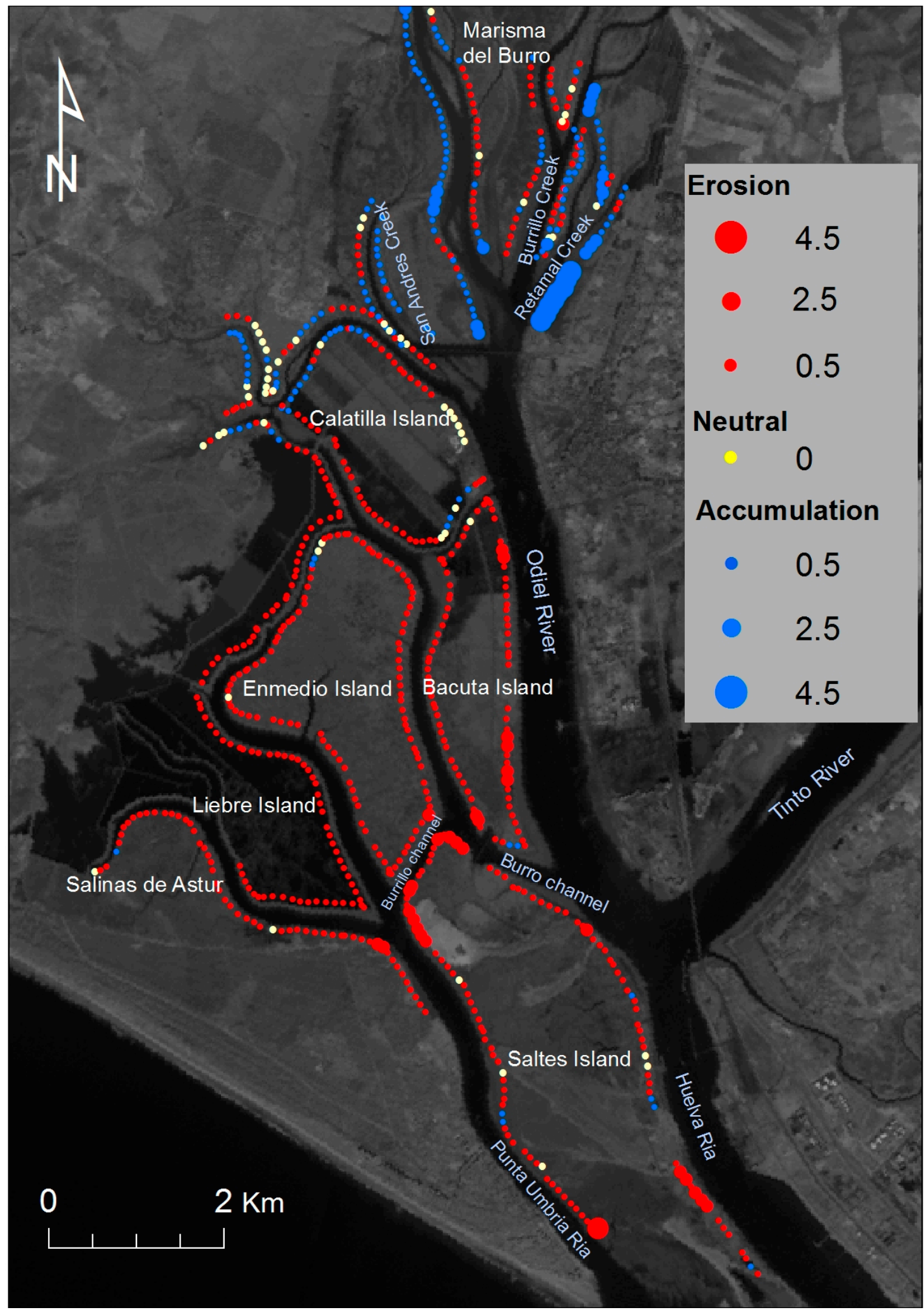

Figure 9. Erosion and sedimentation rates (in $\mathrm{m} \mathrm{year}^{-1}$ ) in the Odiel saltmarshes between 1956 and 2013 (displayed over 1987 spot image), estimated using linear regression (LRR); where red dots mean erosion rates (retreatment), blue dots sedimentation rates (horizontal growth) and yellow dots no shoreline changes. 


\section{Discussion and Conclusions}

SLAMM is an open source model that can be implemented with relative ease. It has been used to investigate potential impacts of sea-level rise on coastal wetlands in a range of locations, though primarily the USA [20,21,41-44]. Here, SLAMM was implemented to explore the role of sea-level rise on Mediterranean-Atlantic saltmarshes using the Odiel system (SW-Spain) as a case study. This has shown that SLAMM could be used for modelling large expanses of saltmarsh, but results need to be handled carefully especially when the fetch is smaller than $9 \mathrm{~km}$. An important limitation of SLAMM lies in its application of lateral erosion, which is not considered when the fetch is smaller than $9 \mathrm{~km}$. This is an important limitation when modelling Mediterranean-Atlantic saltmarshes, and indeed many of the infilled estuaries in Europe where the within-estuary open water is usually much narrower than $9 \mathrm{~km}$.

Lateral erosion is an important process when predicting future saltmarsh response due to sea-level rise, and this rule would need to be modified (as indicated by Reference [45]) when European saltmarshes are investigated where the fetch will be usually smaller than $9 \mathrm{~km}$. Several authors (e.g., References [46,47]) have argued that although a saltmarsh may able to accrete vertically in a context of sea-level rise, lateral erosion due to different factors (anthropogenic and natural) may significantly impact the pioneer zone, thereby inducing higher saltmarsh loss rates. Although there is plenty of sediment supply for the Odiel saltmarshes to accrete vertically [31,34], the saltmarsh loss due to lateral erosion processes is significant and it may induce greater saltmarsh loss in the context of sea-level rise. The interaction of these factors is not modelled by SLAMM under the mentioned conditions and it probably underestimates low marsh and pioneer zone loss.

Aside from the lateral erosion issues, SLAMM could be a helpful tool for detecting sensitive areas within Mediterranean-Atlantic saltmarshes in the context of a rising sea level (e.g., to help to identify vulnerable zones in combination with field data [24], or to identify where wetland migration corridors are crucial [48]). For example, model results can help managers and decision makers to plan adaptation strategies for saltmarshes, and also to define boundaries for further investigation using more complex physical models (e.g., Reference [49]) or individual-based models (e.g., Reference [50]) that may not feasible when landscape scales are used. However, there are many uncertainties related to sea-level rise impacts over saltmarshes and it is important to be aware of these when projections are used to inform saltmarshes and intertidal ecosystem management. The main uncertainties detected here were due to model limitations and data quality.

The first uncertainty detected in saltmarsh modelling was related to the simplification of the saltmarsh processes implemented in SLAMM. Models and empirical relationships used to predict the effects of sea-level rise may simplify relationships (assuming a constant state) [21] and assume that coastal geomorphology does not change as sea level rises, which is unlikely. SLAMM lacks feedback mechanisms that may play an important role as sea-level rise accelerates. For example, increasing inundation of saltmarshes may increase macrophyte production and lead to increased vertical accretion [51]. Additionally, processes governed by the tidal regime are assumed to be constant and therefore with increasing progression from the initial condition into a simulation, uncertainties in model prediction will increase. In this sense, the historical evolution of the studied system plays an important role in identifying the main drivers acting on the system. By considering past behavior, the system response due to past sea-level rise, for instance, can provide useful information for contextualizing the future response of the system. As demonstrated here, uncertainty analysis considering probability distributions becomes essential to assess the probability of different system responses. The accurate definition of these probability distributions is crucial to reduce uncertainty, and historical data should be considered in this process.

The second uncertainty surrounding modelling saltmarsh response to sea-level rise is data source quality and resolution. The resolution of input data is an important factor in spatial models like SLAMM and is usually constrained by data source [22]. Elevation data and habitat map accuracy have been identified here as key components contributing to uncertainty in SLAMM habitat predictions in the context of sea-level rise. Improving the accuracy of the LiDAR-derived DEMs using saltmarsh 
habitat maps [52] is one approach to reduce elevation quality derived uncertainties. It is highly recommended to do a rigorous validation of LiDAR-derived DEMs, especially in saltmarshes where perennial tall vegetation and/or high vegetation density are found. For example, in the case of the Odiel saltmarshes, the LiDAR-derived DEM showed vertical errors of up to $0.5 \mathrm{~m}$ in areas colonized by Spartina densiflora [30].

Apart from uncertainties related to the model and input data, there are also uncertainties directly linked to sea-level rise projections; global sea-level rise by 2100 projections range roughly between 0.28 and $1.4 \mathrm{~m} \mathrm{[3]} \mathrm{and} \mathrm{could} \mathrm{exceed} 2 \mathrm{~m}$ according to more recent studies [10]. Local projections for the Odiel saltmarshes estimated from historical trends and future projections using a correlation factor include $0.64-0.86 \mathrm{~m}$ (IPCC scenarios), 1.07-2.27 $\mathrm{m} \mathrm{[4]}$ and $1.17 \mathrm{~m} \mathrm{[5,53].} \mathrm{Given} \mathrm{the} \mathrm{uncertainty} \mathrm{in}$ future sea-level rise, in combination with spatial habitat conversion that may not well reproduced by predictive models and the site-specific input parameter variability, site-specific projections likely fluctuate in accuracy $[24,54]$. Thus, it is essential to consider uncertainty analysis and update the information based on new research findings when possible.

Finally, management strategies themselves may have uncertain consequences. Robust management decisions require diverse information, predictions and their associated uncertainty [21]. For this purpose, a multi-criteria decision analysis can provide a suitable tool to integrate different information $[55,56]$, including results from several models. Apart of combining SLAMM results with other model outputs in the management strategies, the use of predictive models such as SLAMM could also be used as a tool for assessing the effectiveness of different management measures for instance. Thus, the combination of different tools (including uncertainty analysis) could be the key for managing coastal ecosystems within the uncertain future that they currently face.

Author Contributions: Data curation, M.F.-N. and P.D.-C.; Formal analysis, M.F.-N.; Funding acquisition, J.O.-Z.; Investigation, M.F.-N. and P.D.-C.; Methodology, M.F.-N. and H.B.; Project administration, J.O.-Z.; Resources, J.O.-Z.; Supervision, H.B.; Writing-original draft, M.F.-N.; Writing—review \& editing, H.B.; P.D.-C. and J.O.-Z.

Funding: This study has been developed within two research projects funded by “Ministerio de Economia y competitividad (Plan Nacional), grant number CSO2014-51994-P".

Conflicts of Interest: The authors declare no conflict of interest. The funders had no role in the design of the study; in the collection, analyses, or interpretation of data; in the writing of the manuscript, or in the decision to publish the results.

\section{References}

1. Smith, S.M. Multi-Decadal Changes in Salt Marshes of Cape Cod, MA: Photographic Analyses of Vegetation Loss, Species Shifts, and Geomorphic Change. Northeast. Nat. 2009, 16, 183-208. [CrossRef]

2. Nicholls, R.J. Coastal flooding and wetland loss in the 21st century: Changes under the SRES climate and socio-economic scenarios. Glob. Environ. Chang. 2004, 14, 69-86. [CrossRef]

3. IPCC (Intergovernmental Panel on Climate Change). Climate Change 2014: Synthesis Report. Contribution of Working Groups I, II and III to the Fifth Assessment Report of the Intergovernmental Panel on Climate Change; Pachauri, R.K., Meyer, L.A., Eds.; IPCC: Geneva, Switzerland, 2014; p. 151.

4. Pfeffer, W.T.; Harper, J.T.; O'Neel, S. Kinematic constraints on glacier contributions to 21st-century sea-level rise. Science 2008. [CrossRef] [PubMed]

5. Rahmstorf, S. A semi-empirical approach to projecting future sea-level rise. Science 2007, 315, 368-370. [CrossRef]

6. Meehl, G.A.; Stocker, T.S.; Collins, W.D.; Friedlingstein, P.; Gaye, A.T.; Gregory, J.M.; Kitoh, A.; Knutti, R.; Murhy, J.M.; Nosa, A.; et al. (Eds.) Contribution of Working Group I to the Fourth Assessment Report of IPCC on Climatic Change; Cambridge University Press: Cambridge, UK, 2007; pp. 749-844.

7. Church, J.A.; Clark, P.U.; Cazenave, A.; Gregory, J.M.; Jevrejeva, S.; Levermann, A.; Merrifield, M.A.; Milne, G.A.; Nerem, R.S.; Nunn, P.D.; et al. Sea level change. In Climate Change, 2013: The Physical Science Basis; Stocker, T.F., Qin, D., Plattner, G.-K., Tignor, M., Allen, S.K., Boschung, J., Nauels, A., Xia, Y., Bex, V., Midgley, P.M., Eds.; Contribution of Working Group I to the Fifth Assessment Report of the Intergovernmental Panel on Climate Change; Cambridge University Press: Cambridge, UK; New York, NY, USA, 2013. 
8. Vermeer, M.; Rahmstorf, S. Global sea level linked to global temperature. Proc. Natl. Acad. Sci. USA 2009, 106, 21527-21532. [CrossRef] [PubMed]

9. Jevrejeva, S.; Moore, J.C.; Grinsted, A. Sea level projections to AD2500 with a new generation of climate change scenarios. Glob. Planet Chang. 2012, 80-81, 14-20. [CrossRef]

10. DeConto, R.M.; Pollard, D. Contribution of Antarctica to past and future sea-level rise. Nature 2016, 531, 591-597. [CrossRef] [PubMed]

11. Oppenheimer, M.; Alley, R.B. How high will the seas rise? Science 2016, 354, 1375-1377. [CrossRef]

12. Pugh, D.T. Tides, Surges and Mean Sea-Level; John Wiley \& Sons Ltd.: New York, NY, USA, 1996.

13. Rybczyk, J.M.; Callaway, C. Surface Elevation Models. In Coastal Wetlands: An Intergrated Ecosystem Approach; Perillo, G.M.E., Wolanski, E., Cahoon, D.R., Brinson, M.M., Eds.; Elsevier: Amsterdam, The Netherland, 2009; pp. 835-853.

14. French, J. Tidal marsh sedimentation and resilience to environmental change: Exploratory modelling of tidal, sea-level and sediment supply forcing in predominantly allochthonous systems. Mar. Geol. 2006, 235, 119-136. [CrossRef]

15. Barbier, E.B. Valuing Ecosystem Services for Coastal Wetland Protection and Restoration: Progress and Challenges. Resources 2013, 2, 213-230. [CrossRef]

16. Hartig, E.K.; Gornitz, V.; Kolker, A.; Mushacke, F.; Fallon, D. Anthropogenic and climate-change impacts on salt marshes of Jamaica Bay, New York City. Wetlands 2002, 22, 71-89. [CrossRef]

17. Luo, S.; Shao, D.; Long, W.; Liu, Y.; Sun, T.; Cui, B. Assessing 'coastal squeeze' of wetlands at the Yellow River Delta in China: A case study. Ocean Coast. Manag. 2018, 153, 193-202. [CrossRef]

18. Park, R.A.; Manjit, S.T.; Mauseland, P.W.; Howe, R.C. The Effects of Sea Level Rise on US Coastal Wetlands. The Potential Effects of Global Climate Change on the United States: Appendix B-Sea Level Rise; U.S. Environmental Protection Agency: Washington, DC, USA, 1989.

19. Clough, J.; Polaczyk, A.; Propato, M. Modeling the potential effects of sea-level rise on the coast of New York: Integrating mechanistic accretion and stochastic uncertainty. Environ. Model. Softw. 2016, 84, 349-362. [CrossRef]

20. Hauer, M.E.; Evans, J.M.; Alexander, C.R. Sea-level rise and sub-county population projections in coastal Georgia. Popul. Environ. 2015, 37, 44-62. [CrossRef]

21. Linhoss, A.C.; Kiker, G.A.; Aiello-Lammensc, M.A.; Chu-Agor, L.; Convertino, M.; Muñoz-Carpena, R.; Fischere, R.; Linkov, I. Decision analysis for species preservation under sea-level rise. Ecol. Model. 2013, 263, 264-272. [CrossRef]

22. Murdukhayeva, A.; August, P.; Bradley, M.; LaBash, C.; Shaw, N. Assessment of Inundation Risk from Sea Level Rise and Storm Surge in Northeastern Coastal National Parks. J. Coast. Res. 2013, 29, 1-16. [CrossRef]

23. Sherwood, E.T.; Greening, S. Potential impacts and management implications of climate change on Tampa Bay estuary critical coastal habitats. Environ. Manag. 2014, 53, 401-415. [CrossRef]

24. Cole Ekberg, M.L.; Raposa, K.B.; Ferguson, W.F.; Ruddock, K.; Burke Watson, E. Development and Application of a Method to Identify Salt Marsh Vulnerability to Sea Level Rise. Estuar. Coast. 2017, 40, 694-710. [CrossRef]

25. Gehu, J.M.; Rivas-Martinez, S. Classification of European salt plant communities. In Salt Marsh in Europe; Dijkema, K.S., Ed.; Council of Europe: Strasbourg, France, 1984; pp. 34-40.

26. Orson, R.; Panageotou, W.; Leatherman, S.P. Response of tidal salt marshes of the US Atlantic and Gulf coasts to rising sea levels. J. Coast. Res. 1985, 1, 29-37. [CrossRef]

27. Ojeda, J. Las Costas Andaluzas. In Geografía de Andalucía; López, A., Ed.; Ariel: Sevilla, España, 2003; pp. 118-135.

28. Arnaud-Fassetta, G.; Bertrand, F.; Costa, S.; Davidsonc, R. The western lagoon marshes of the Ria Formosa (Southern Portugal): Sediment-vegetation dynamics, long-term to short-term changes and perspective. Cont. Shelf Res. 2006, 26, 363-384. [CrossRef]

29. Clough, J.S.; Park, R.A.; Fuller, J. SLAMM 6 Beta Technical Documentation SLAMM 6 Technical Documentation. 2010; p. 51. Available online: http://warrenpinnacle.com/prof/SLAMM6/SLAMM6_ Technical_Documentation.pdf (accessed on 8 March 2019).

30. Fernandez-Nunez, M.; Burningham, H.; Ojeda, J. Improving accuracy of LiDAR-derived digital terrain models for saltmarsh management. J. Coast. Conserv. 2017, 21, 209-222. [CrossRef] 
31. Fernandez-Nunez, M. Fusion of Airborne LiDAR, Multispectral Imagery and Spatial Modelling for Understanding Saltmarsh Response to Sea-Level Rise. Ph.D. Thesis, University College London, London, UK, February 2017.

32. Rubio, J.C.; Figueroa, M.E. Medio Físico, Vegetación de las Marismas de los ríos Odiel y Tinto (Huelva). Estudios Territoriales 1983, 9, 59-86.

33. Chu-Agor, M.L.; Muñoz-Carpena, R.; Kiker, G.; Emanuelsson, A.; Linkov, I. Exploring vulnerability of coastal habitats to sea level rise through global sensitivity and uncertainty analyses. Environ. Model. Softw. 2011, 26, 596-604. [CrossRef]

34. Permanent Service for Mean Sea Level (PSMSL). Available online: https:/ /www.psmsl.org/ (accessed on 16 June 2018).

35. Morales, J.A.; Gutiérrez de San Miguel, E.; Borrego, J.E. Tasas de sedimentation reciente en la Ria de Huelva. Geogaceta 2003, 33, 15-18.

36. Sobol, I.M. Sensitivity estimates for non-linear mathematical models. Math. Model. Comput. Exp. 1993, 4, 407-414.

37. Pajak, M.J.; Leatherman, S.P. The High Water Line as Shoreline Indicator. J. Coast. Res. 2002, 18, 329-337.

38. Himmelstoss, E.A. Dsas 4.0. Instructions Installation Guide User. In Digital Shoreline Analysis System (DSAS) Version 4.0-An ArcGIS Extension for Calculating Shoreline Change: U.S. Geological Survey Open-File Report 2008-1278; Thieler, E.R., Himmelstoss, E.A., Zichichi, J.L., Ergul, A., Eds.; USGS Numbered Series; U.S. Geological Survey: Reston, VA, USA, 2009. [CrossRef]

39. Garrote, J.; Díaz-Álvarez, A.; Nganhane, H.V.; Garzón Heydt, G. The Severe 2013-2014 Winter Storms in the Historical Evolution of Cantabrian (Northern Spain) Beach-Dune Systems. Geosciences 2018, 8, 459. [CrossRef]

40. Manno, G.; Lo Re, C.; Ciraolo, G. Uncertainties in shoreline position analysis: The role of run-up and tide in a gentle slope beach. Ocean Sci. 2017, 13, 661-671. [CrossRef]

41. Craft, C.; Clough, J.; Ehman, J.; Joye, S.; Park, R.; Pennings, S.; Guo, H.; Machmuller, M. Forecasting the effects of accelerated sea-level rise on tidal marsh ecosystem services. Front. Ecol. Environ. 2009, 7, 73-78. [CrossRef]

42. Akumu, C.E.; Sumith, P.; Baban, S.; Bucher, D. Examining the potential impacts of sea level rise on coastal wetlands in north-eastern NSW, Australia. J. Coast. Conserv. 2010, 15, 15-22. [CrossRef]

43. Woodland, R.J.; Rowe, C.L.; Henry, F.P.P. Changes in Habitat Availability for Multiple Life Stages of Diamondback Terrapins (Malaclemys terrapin) in Chesapeake Bay in Response to Sea Level Rise. Estuar. Coast. 2017, 40, 1502-1515. [CrossRef]

44. Wu, W.; Zhou, Y.; Tian, B. Coastal wetlands facing climate change and anthropogenic activities: A remote sensing analysis and modelling application. Ocean Coast. Manag. 2017, 138, 1-10. [CrossRef]

45. Pylarinou, A. Impacts of Climate Change on UK Coastal and Estuarine Habitats: A Critical Evaluation of the Sea Level Affecting Marshes Model (SLAMM). Ph.D. Thesis, University College London, London, UK, 2015.

46. Castillo, J.M.; Luque, C.J.; Castellanos, E.M.; Figueroa, M.E. Causes and consequences of salt-marsh erosion in an Atlantic estuary in SW Spain. J. Coast. Conserv. 2000, 6, 89-96. [CrossRef]

47. Wolters, M.; Bakker, J.P.; Bertness, M.D.; Jefferies, R.L.; Möller, I. Saltmarsh erosion and restoration in south-east England: Squeezing the evidence requires realignment. J. Appl. Ecol. 2005, 42, 844-851. [CrossRef]

48. Borchert, S.M.; Osland, M.J.; Enwright, N.M.; Griffith, K. Coastal wetland adaptation to sea level rise: Quantifying potential for landward migration and coastal squeeze. J. Appl. Ecol. 2018, 55, 2876-2887. [CrossRef]

49. French, J.R. Numerical Simulation of Vertical Marsh Growth and Adjustment to Accelerated Sea-Level Rise, Norfolk, U.K. Earth Surf. Proc. Land 1993, 18, 63-81. [CrossRef]

50. Wood, K.A.; Stillman, R.; Goss-Custard, J.D. Co-creation of individual-based models by practitioners and modellers to inform environmental decision-making. J. Appl. Ecol. 2015, 52, 810-815. [CrossRef]

51. Morris, J.T.; Sundareshwar, P.V.; Nietch, C.T.; Kjerfve, B.; Cahoon, D.R. Responses of coastal wetlands to rising sea level. Ecology 2002, 83, 2869-2877. [CrossRef]

52. Hladik, C.; Schalles, J.; Alber, M. Salt marsh elevation and habitat mapping using hyperspectral and LIDAR data. Remote Sens. Environ. 2013, 139, 318-330. [CrossRef]

53. Fraile-Jurado, P.; Fernandez-Diaz, M. Escenarios de subida del nivel medio del mar en los mareógrafos de las costas peninsulares de España en el año 2100. Estud. Geogr. 2016, 280, 57-79. [CrossRef] 
54. Passeri, D.L.; Hagen, S.C.; Medeiros, S.C.; Bilskie, M.V.; Alizad, K.; Wang, D. The dynamic effects of sea level rise on low-gradient coastal landscapes: A review. Earth's Future 2015, 3, 159-181. [CrossRef]

55. Kiker, G.A.; Bridges, T.S.; Kim, J. Integrating comparative risk assessment with multi-criteria decision analysis to manage contaminated sediments: An example from New York/New Jersey Harbor. Hum. Ecol. Risk Assess. 2008, 14, 495-511. [CrossRef]

56. Linkov, I.; Satterstrom, F.K.; Kiker, G.A.; Batchelor, C.; Bridges, T.S.; Fergusson, E. From comparative risk assessment to multi-criteria decision analysis and adaptive management: Recent developments and applications. Environ. Int. 2006, 32, 1072-1093. [CrossRef] [PubMed]

2019 by the authors. Licensee MDPI, Basel, Switzerland. This article is an open access article distributed under the terms and conditions of the Creative Commons Attribution (CC BY) license (http://creativecommons.org/licenses/by/4.0/). 